\title{
Does Phenoloxidase Contributed to the Resistance? Selection with Butane- Fipronil Enhanced its Activities from Diamondback Moths
}

\author{
Shouzhu Liu ${ }^{1,2}$, Hongtao $\mathrm{Niu}^{2}$, Ting $\mathrm{Xiao}^{3}$, Chaobin $\mathrm{Xue}^{2}$, Zhongde Liu ${ }^{4}$ and Wanchun Luo*,2 \\ ${ }^{1}$ College of Agriculture, Liaocheng University, Liaocheng 252059, China \\ ${ }^{2}$ College of Plant Protection, Shandong Key Laboratory of Pesticide Toxicology and Application Technique, Shandong \\ Agricultural University, Tai'an 271018, China \\ ${ }^{3}$ Institute of Zhenjiang Agricultural Sciences Jiangsu Hill Region, Jurong Jiangsu 212400, China \\ ${ }^{4}$ College of life science and technique, Taishan University, Tai'an 271000, China
}

\begin{abstract}
Using microtitration method, the relationship between Phenoloxidase activity and the resistance of the diamondback moth Plutella xylostella (Linnaeus) to the novel insecticide butane-fipronil was determined in vitro. After selection of the tenth-generation by butane-fipronil, the resistance of the fourth instar larvae was increased 83.80-fold as compared to the susceptible strain. Phenoloxidase activity of the resistant strain $\left(\mathrm{PO}_{\mathrm{r}}\right)$ was 1.29 -fold higher than the susceptible one $\left(\mathrm{PO}_{\mathrm{s}}\right)$. However, the $\mathrm{K}_{\mathrm{m}}$ and optimum $\mathrm{pH}$ values were similar in resistant and susceptible strains, which were $1.11 \mathrm{mM}$ and 6.5, respectively. Both $\mathrm{PO}_{\mathrm{r}}$ and $\mathrm{PO}_{\mathrm{s}}$ have maximum stability at $\mathrm{pH}$ values less than 7.0, although $\mathrm{PO}_{\mathrm{s}}$ was less stable at lower $\mathrm{pH}$ values than $\mathrm{PO}_{\mathrm{r}}$. In addition, the thermal stabilities of the two phenoloxidase were very similar. It is suggested that PO may play an important role in the increasing resistance of pests to pesticides.
\end{abstract}

Keywords Butane-fipronil, phenoloxidase, Plutella xylostell, resistance.

\section{INTRODUCTION}

The diamondback moth, Plutella xylostella (Linnaeus), is one of the most widely distributed insects in the world and lives in more than 80 countries [1]. The indiscriminate use of insecticides coupled with the ability of $P$. xylostella $\mathrm{L}$. to produce multiple generations per annum and the high migratory potential of the species has led to its resistance to many insecticides [2,3]. It has been shown that the resistance occurring included alterations to insecticide target sites and powerful metabolic resistance catalyzed by some enzyme such as mixed function oxidase, esterase or glutathione-stransferases [4]. For example, the chlorfluazuro-resistant $P$. xylostella has higher glutathione S-transferase-3 (GST-3) gene expression and GST activity, suggesting that GST-3 is involved in chlorfluazuron detoxification in diamondback moths [5]. While no differences in detoxication enzyme activities of permethrin-selected diamondback moths compared to non-selected populations have been found, the observed pyrethroid resistance is most likely due to decreased target site sensitivity [6].

Fipronil is the first member of the phenylpyrazole group of insecticides, and is highly toxic to both piercing-sucking and chewing insects. In addition, it has shown excellent activity against a broad spectrum of insect orders [7], with no obvious cross-resistance to other insecticides with different mechanisms of action [8]. Its resistance mechanism was demonstrated as involving low cuticle permeability, monooxygenase metabolism and increased activity of detoxi-

*Address correspondence to this author at the College of Plant Protection, Shandong Agricultural University, Shandong, Tai'an 271018, China; Tel: +86 538 8242983; Fax: +86 538 8242983; E-mail: wcluo@ sdau.edu.cn fication enzymes in Musca domestica, Plutella oxylostella, and Chilo suppressalis [9-12]. Butene-fipronil is a novel compound obtained via the structural modification of phenylpyrazole. It has similar activity as fipronil in controlling pests on rice and vegetable crops, and has low toxicity to fish, which makes it an excellent pesticide [13].

Phenoloxidase (PO) (EC 1.14.18.1), also known as tyrosinase, is one of the key enzymes of the insect molting process, which is involved in hardening and stabilizing the newly secreted exoskeleton. Phenoloxidase catalyzes the oxidation of various phenolic compounds to the corresponding quinones, and then quinones combine with proteins to form the hard dark-colored layer of the cuticle [14]. Phenoloxidases have been proposed to participate in cuticle tanning. Arakane et al. reported that phenoloxidases extracted from Tribolium castaneum are required for larval, pupal, and adult cuticle sclerotization and pigmentation [15]. Phenoloxidase is also a key enzyme of insect immune response, and can be found in cuticular matrix [16], hemocytes [17], and hemolymph [18].

It is known that insecticide resistance is due to behavioral changes, physiological modifications, and metabolic detoxification [19]. Insect cuticle penetration is involved in physiological modifications, and some insecticides must pass through the insect cuticle in order to reach the site of action before lethal effects can occur. Some reports indicated that decreased penetration confers 2-3 fold resistance by itself $[20,21]$. There have been no reports regarding phenoloxidase (PO) activity in insecticide resistance, although PO is involved in hardening and stabilizing the newly secreted exoskeleton. In fact, more attention must be paid to this enzyme when studying insecticide resistance, because PO is 
one of the key enzymes of the insect molting process. In addition, PO influences the cuticle structure to allow insecticide penetration.

In the present paper, PO activity and the properties of the resistant and the susceptible diamondback moth $P$. xylostella L. are investigated, the relationship between PO and pest resistance are also discussed. The results of this study may lead to a better understanding of the mechanism of pest resistance.

\section{MATERIALS AND METHODOLOGY}

\section{Chemicals and Instruments}

L-Dihydroxyphenylalanine (L-DOPA) was purchased from Sigma (USA), and butane-fipronil (97\%) was supplied by Dalian Raiser Pesticide Co. LTD (China). All other reagents were local products of analytical grade. The 96-well microtiter plate reader used was a Thermo Mustiskan Mk3 (Thermo electron corporation).

\section{Insect}

The susceptive diamondback moth strain was reared on Chinese cabbage Brassica parachinesi (Bailey) in a greenhouse at $25 \pm 1{ }^{\circ} \mathrm{C}$ with a $14: 10 \mathrm{~h}$ light:dark cycle, and had never been exposed to insecticides [22]. Half of the susceptive strain population was selected for resistance to butanefipronil for 10 generations to make the resistant strain, using dipping methods described by Ismail F. [23]. Briefly, butane-fipronil was dissolved in acetone and five serially diluted concentrations were prepared with distilled water containing $0.05 \%$ triton $X-100$. Cabbage leaves $(4 \mathrm{~cm} \times 4 \mathrm{~cm})$ were cut and dipped in the serially diluted solution for $10 \mathrm{~s}$. Three-day-old third instar larvae of parental generations were allowed to feed on the butane-fipronil treated leaf for $48 \mathrm{~h}$, followed by a fresh leaf until it pupaed.

\section{Resistant Selection Bioassay}

Technical grade butane-fipronil was dissolved in acetone and five serially experimental concentrations were prepared after protest to larvae of diamonback moth. Then fourthinstar larvae (2-3 mg/larva) were treated with $0.3 \mu \mathrm{L}$ of the dilution on the mesothorax notum by a hand microapplicator to determine the median lethal concentration $\left(\mathrm{LC}_{50}\right)$. Each test was repeated six times and acetone treatment was used as a control [24].

\section{Preparation and Purification of PO}

Fourth instar larvae (about $4 \mathrm{~g}$ ) of the two strains were homogenized using a blender in ice-cold extraction buffer [20 mL, 0.02 M phosphate buffer solution (PBS), pH 6.5]. The homogenates were centrifuged at $6770 \mathrm{~g}$ for $30 \mathrm{~min}$. The supernatant was collected and brought to $40 \%$ saturation with solid ammonium sulfate. The precipitate was collected by centrifugation at $6770 \mathrm{~g}$ for $30 \mathrm{~min}$, redissolved in a minimum volume of the same buffer, and dialyzed against $20 \mathrm{mM}$ PBS ( $\mathrm{pH} 6.5$ ) for $40 \mathrm{~h}$. The partially purified enzyme was used in the present investigation.

\section{Protein Estimation}

Total protein concentration was determined by Coomassie blue G-250 dye-binding using bovine serum albumin as the standard [25].

\section{PO Assay}

Phenoloxidase activity was assayed by determining the initial linear increase in absorbance at $490 \mathrm{~nm}$ using a Thermo Mustiskan Mk3 microtiter plate reader at room temperature, using L-dihydroxyphenylalanine (L-DOPA) as the substrate. The reading was taken instantly after enzyme addition.

\section{Assay of Optimal pH and Stability of PO Under Different pH Conditions}

The optimum $\mathrm{pH}$ and the $\mathrm{pH}$ stability were determined according to Xue et al. [26]. Briefly, to determine the optimum $\mathrm{pH}, 140 \mu \mathrm{L}$ of different buffers ( $\mathrm{pH}$ range: 4.4-9.0), and $40 \mu \mathrm{L}$ of $10 \mathrm{mM}$ L-DOPA were added to a microtiter plate well. Next, $20 \mu \mathrm{L}$ of enzyme $(103.55 \mathrm{mg} / \mathrm{mL}$, as same below) was added to each reaction mixture, and the plate was read immediately to record the absorbance at $490 \mathrm{~nm}$ at room temperature.

To determine the $\mathrm{pH}$ stability of $\mathrm{PO}, 20 \mu \mathrm{L}$ of enzyme was added to $180 \mu \mathrm{L}$ of reaction mixture $(140 \mu \mathrm{L}$ of buffer, $40 \mu \mathrm{L}$ of $10 \mathrm{mM}$ L-DOPA) under different $\mathrm{pH}$ conditions to assay the PO activity (as full activity). Another $20 \mu \mathrm{L}$ of enzyme was added to $140 \mu \mathrm{L}$ of different buffers, and incubated for $30 \mathrm{~min}$ at $4{ }^{\circ} \mathrm{C}$ before $40 \mu \mathrm{L}$ of $10 \mathrm{mM}$ L-DOPA was added and the remaining PO activity was assayed immediately at room temperature. The specific value of the remaining activity to full activity was used to evaluate PO stability.

\section{Assay of PO Thermal Stability}

To test the thermal stability of PO, $20 \mu \mathrm{L}$ of enzyme was incubated at different temperatures $\left(25^{\circ} \mathrm{C}, 30^{\circ} \mathrm{C}, 35^{\circ} \mathrm{C}, 40^{\circ} \mathrm{C}\right.$, $50^{\circ} \mathrm{C}, 60^{\circ} \mathrm{C}, 80^{\circ} \mathrm{C}$ ) for $5 \mathrm{~min}$ and $15 \mathrm{~min}$, and then added to $180 \mu \mathrm{L}$ of reaction mixture (containing $40 \mu \mathrm{L}$ of $10 \mathrm{mM} \mathrm{L}$ DOPA, and $140 \mu \mathrm{L}$ of PBS, $\mathrm{pH} 6.5$ ) to assay the PO activity immediately. The thermal stability was evaluated by the ratio of remaining $\mathrm{PO}$ activity.

\section{RESULTS}

\section{Resistance Selection}

The responses of the fourth instar larvae of $P$. xylostella to butene-fipronil in different generations of the susceptible and resistant strains after selection are presented in Fig. (1). The resistance of the fourth instar larvae of Plutella xylotella (L.) diamondback moths to butene-fipronil increased 83.80fold in comparison with the susceptible strain until the election for the tenth generation. The resistance ratio of the parental generation increased 78.02-fold after nine generations of selection. In the experimens the eighth generation was not selected by butene-fipronil. Results showed that at the first three generations and the last three generations, the resistance increased slowly.

\section{Determination of Kinetic Parameters of PO}

Under the conditions employed in the present study, the oxidization of L-DOPA by P. xylostella PO followed Michaelis-Menten kinetics. The kinetic parameters for the enzyme were determined using a Lineweaver-Burk plot, with the results shown in Fig. (2). The $K_{\mathrm{m}}$ and $V_{\max }$ values for $\mathrm{PO}$ from the butane-fipronil resistant strain $\left(\mathrm{PO}_{\mathrm{r}}\right)$ were 1.108 $\mathrm{mM}$ and $153.84 \mu \mathrm{mol} / \mathrm{L} \cdot \mathrm{min}^{-1} \cdot \mathrm{mg}^{-1}$ protein, respectively, 


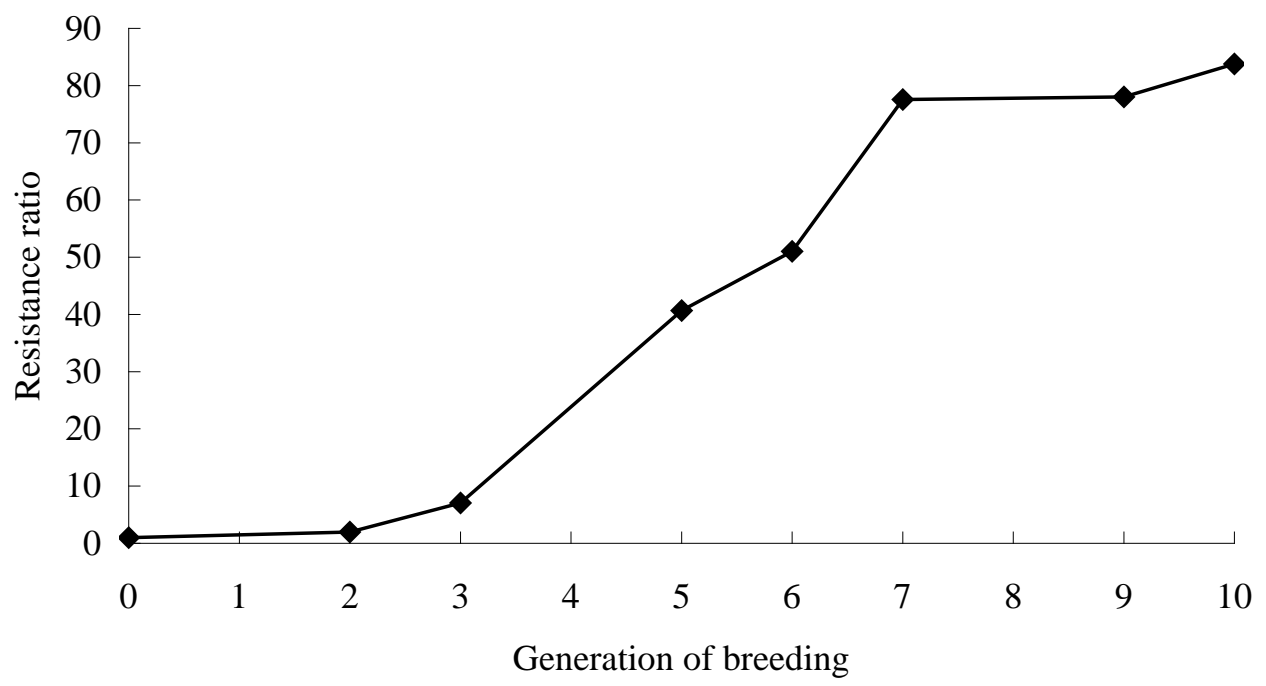

Fig. (1). The resistance curve of diamondback moths to butene-fipronil in various generations.

while the $K_{\mathrm{m}}$ and $V_{\max }$ values for the PO from the susceptible strain $\left(\mathrm{PO}_{\mathrm{s}}\right)$ were $1.114 \mathrm{mM}$ and $67.114 \mu \mathrm{mol} / \mathrm{L} \cdot \mathrm{min}^{-1} \cdot \mathrm{mg}^{-1}$ protein, respectively.

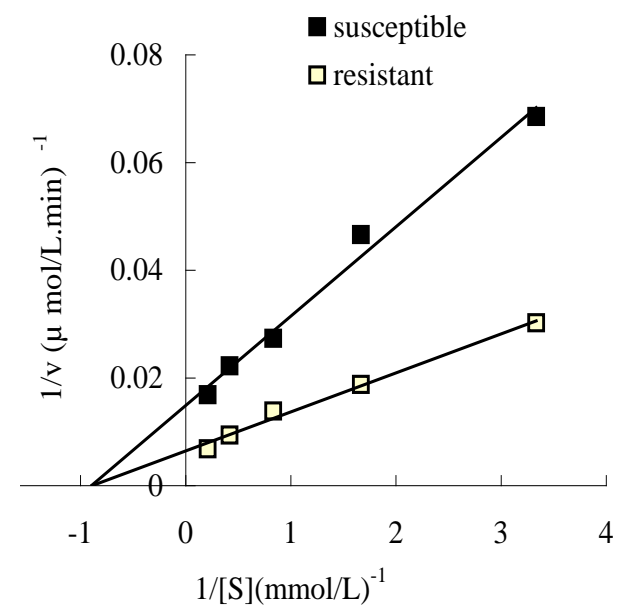

Fig. (2). Lineweaver-Burk plot for the determination of $K_{\mathrm{m}}$ and $V_{\max }$ for phenoloxidase oxidation of L-DOPA at room temperature. Assay conditions were $20 \mathrm{mM}$ PBS ( $\mathrm{pH}$ 6.5), containing 0.3, 0.6, $1.2,2.4,4.8 \mathrm{mM} \mathrm{L}-\mathrm{DOPA}$, and $20 \mu \mathrm{L}$ of enzyme, total volume was $200 \mu \mathrm{L}$. 口: Lineweaver-Burk plot of phenoloxidase from the susceptible strain. $\square$ : Lineweaver-Burk plot of phenoloxidase from the resistant strain.

\section{Effect of pH on Enzyme Activity and pH Stability}

The optimum $\mathrm{pH}$ for $\mathrm{PO}$ was determined to be about 6.5 (Fig. 3). The enzyme activity decreased rapidly when the $\mathrm{pH}$ was higher or lower than 6.5. The optimum $\mathrm{pH}$ of $\mathrm{PO}_{\mathrm{r}}$ was the same as $\mathrm{PO}_{\mathrm{s}}$. Interestingly, when $\mathrm{PO}_{\mathrm{s}}$ was added to the $\mathrm{pH} 4.4$ and $\mathrm{pH} 5.3$ buffers, some floccules appeared; but only in $\mathrm{pH} 4.4$ buffer did $\mathrm{PO}_{\mathrm{r}}$ turn into floccules.

After the enzyme was incubated in different $\mathrm{pH}$ buffers, the remaining activity was assayed, and the specific value of remaining activity to full activity was calculated (Fig. 4).
The maximum stability of $\mathrm{PO}_{\mathrm{r}}$ and $\mathrm{PO}_{\mathrm{s}}$ was at $\mathrm{pH} 7.0$ (the specific values were 0.94 and 0.88 , respectively), with no obvious differences between them. As much of the PO became insoluble, the PO activity (from susceptible larvae) at $\mathrm{pH} 4.4$ and $\mathrm{pH} 5.3$, and the $\mathrm{PO}$ activity from resistant larvae at $\mathrm{pH} 4.4$ were not determined.

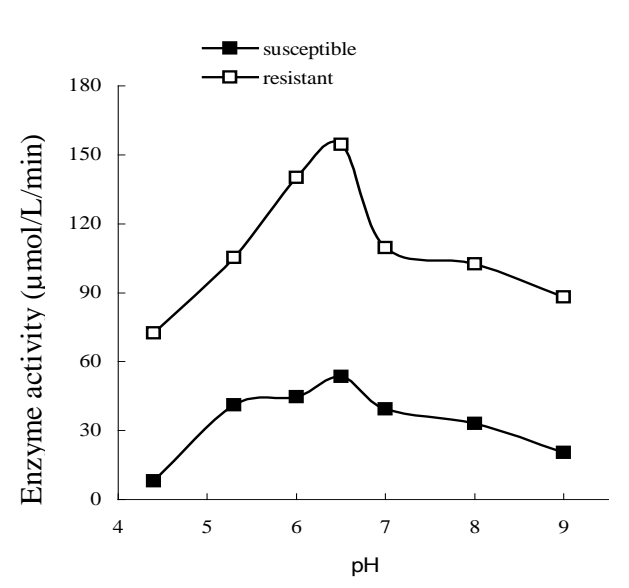

Fig. (3). Optimum $\mathrm{pH}$ for phenoloxidase activity.

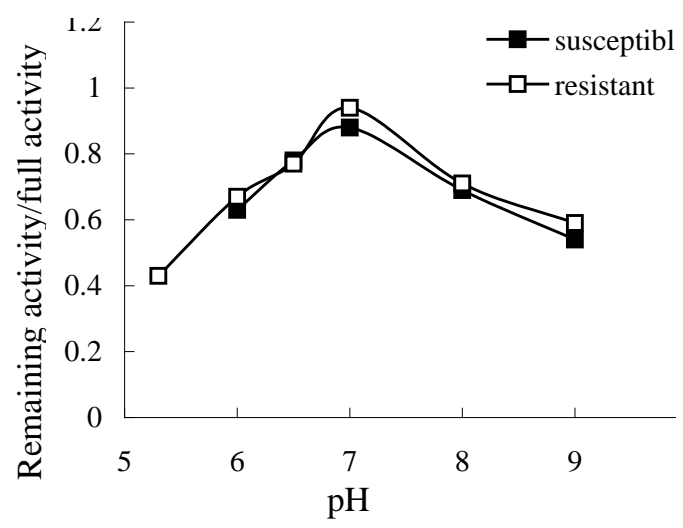

Fig. (4). pH stability of phenoloxidase. 


\section{Thermal Stability of PO}

After the enzyme was incubated at different temperatures $\left(25^{\circ} \mathrm{C}, 30^{\circ} \mathrm{C}, 35^{\circ} \mathrm{C}, 40^{\circ} \mathrm{C}, 50^{\circ} \mathrm{C}, 60^{\circ} \mathrm{C}, 80^{\circ} \mathrm{C}\right)$ for $5 \mathrm{~min}$ and $15 \mathrm{~min}$, the remaining $\mathrm{PO}$ activity was assayed. The results showed that both $\mathrm{PO}_{\mathrm{r}}$ and $\mathrm{PO}_{\mathrm{s}}$ are relatively stable in the range from $25{ }^{\circ} \mathrm{C}$ to $40{ }^{\circ} \mathrm{C}$. However, when the temperature was going greater than $40{ }^{\circ} \mathrm{C}$ the enzyme activity decreased rapidly (Fig. 5). When the temperature reached $80{ }^{\circ} \mathrm{C}$ the enzyme was completely denatured and no enzyme activity was detected (data not shown).

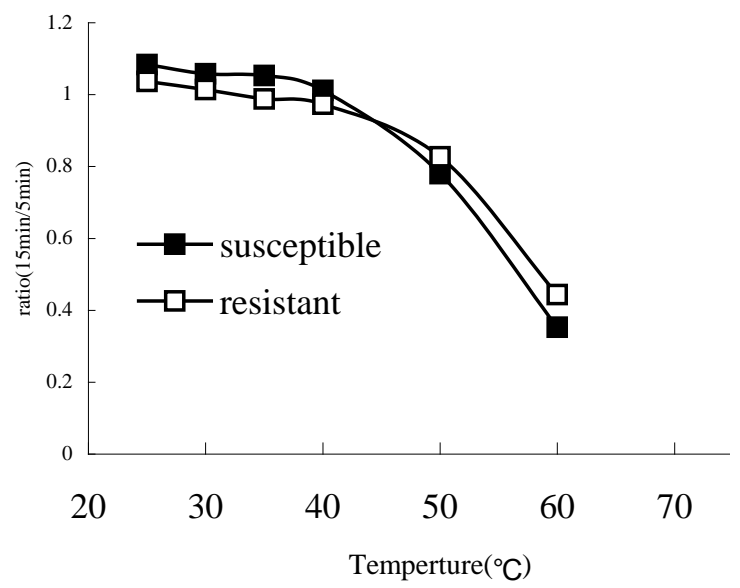

Fig. (5). Stability of phenoloxidase at different temperatures. The ratio of remaining PO activity after a 15 min incubation to PO activity after a $5 \mathrm{~min}$ incubation was calculated.

\section{DISCUSSION AND CONCLUSION}

Using microtitration, the PO activity of $P$. xylostella selected for resistance to butane-fipronil was investigated. The resistant strain was found to have significantly higher PO activity than the susceptible strain, but the difference in PO activity between the two strains could not be explained by variations in total protein content $\left(\mathrm{PO}_{\mathrm{r}}: \mathrm{PO}_{\mathrm{s}}\right.$ was $1.5: 1$ for a 20 $\mu \mathrm{L}$ enzyme sample). This result is similar to data obtained with Sydney rock oysters Saccostrea glomerata [27] in which resistance was selected for QX disease for three generations, and its PO activity was found to be higher than in the non-selected populations. In addition, a novel form of PO protein in selected oysters was detected by native PAGE. In the present paper, $\mathrm{PO}_{\mathrm{r}}$ and $\mathrm{PO}_{\mathrm{s}}$ had the same $K_{m}$ values, indicating that they have the same catalysis ability but whether they are the same proteins is still unknown.

Armitage and Siva-Jothy [28] reported that Tenebrio molitor beetle adults with darker cuticular color have higher PO activity. Also, the black larvae of Bombyx mori silkworms have higher PO activities than white larvae [29]. In the present study, the insect $P$. xylostella was selected for ten generations, and the cuticles of larvae were darker than in the non-selected larvae. We deduced that the darkened cuticle has more PO content which can catalyze more phenolic compounds to quinones, and the melanin content is also increased during this time. This is beneficial for defense against the penetration of butane-fipronil or infection of microorganisms.
On the other hand, insects have an unusual innate immune system and PO is the key enzyme responsible for melanization [30]. For instance, microorganism-infected locusts can form many black nodules to eliminate invaders [31]. Undoubtedly, PO plays a major role in the innate response of insects towards infection. Some chemicals, such as the pesticide monocrotophos, can cause the PO activity to increase in the hemolymph of Penaeus chinensis [32]; chlorfluazuron can also increase the PO activity in the cuticle of Ostrinia furnacalis [33]. In our previously work [34], the physiological effect of quercetin, an inhibitor of $\mathrm{PO}$, was determined in vivo on Tenebrio molitor, results suggested that quercetin at low concentration can cause immune response to the tested insect. The response of PO to chemicals suggests that PO may participate in the detoxification of insects by immune response. With more PO content, insects will easily survive from all kinds of invaders, including pesticides. The fact that butane-fipronil selected $P$. xylostella has higher PO activity supports this view.

So, the contribution of PO to the resistance of P. xylostella to butane-fipronil can be attributed to two aspects: lower cuticle penetration and higher immune ability (Fig. 6).

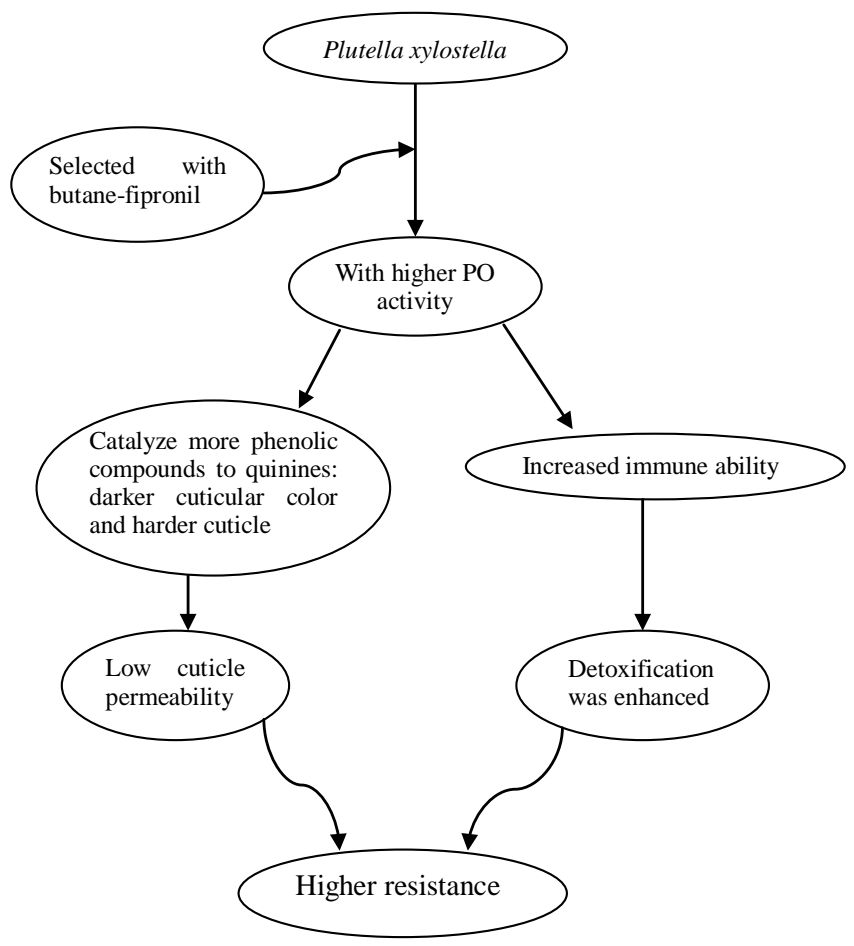

Fig. (6). Two pathways of phenoloxidase contributed to P. xylostella resistance to butane-fipronil.

Although the enzyme activity of $\mathrm{PO}_{\mathrm{r}}$ was higher than $\mathrm{PO}_{\mathrm{s}}$ they have similar $K_{m}$ and optimum $\mathrm{pH}$ values or thermal stabilities. The only notable difference was that $\mathrm{PO}_{\mathrm{r}}$ was stable under $\mathrm{pH} 5.3$ conditions, while $\mathrm{PO}_{\mathrm{s}}$ were unstable under the same conditions. Maybe this phenomenon is due to different protein content in the reaction mixtures.

It was be concluded that the resistance-selected diamondback moths $P$. xylostella have higher PO activity than the susceptible ones. Consequently, PO may play an impor- 
tant role in the increasing resistance of pests to pesticides, the detailed mechanism of which needs further study.

\section{ACKNOWLEDGMENTS}

This work was supported by a Grant from the National Natural Science Foundation of China (NO. 30571237 to Wanchun Luo) and the Expert National ministry of education Foundation of China (NO. 20070434006 to Wan Chun Luo).

\section{REFERENCES}

[1] Harcourt, D.G. Biology of the diamondbackmoth, Plutella maculipennis (Curt.) (Lepidoptera: Plutellidae) in eastern Ontario. I. Distribution, economic history, synonomy and general description. 37th Report of the Quebec Society for the Protection of Plants. 1956, pp 155-160.

[2] Sayyed, A.H.; Wright, D.J. Fipronil resistance in the diamondback moth (Lepidoptera: Plutellidae): inheritance and number of genes involved. J. Econ. Entomol., 2004, 97, 2043-2050.

[3] Sayyed, A.H.; Omar, D.; Wright, D.J. Genetics of spinosad resistance in a multi-resistant field-selected population of Plutella xylostella. Pest Manag. Sci., 2004, 60, 827-832.

[4] Denholm, I.; Devine, G. Insecticide resistance. In: Encyclopedia of Biodiversity; Levin S.A. Ed. San Diego: Academic Press, 2001, pp. 465-477.

[5] Sonoda, S.; Tsumuki, H. Studies on glutathione S-transferase gene involved in chlorfluazuron resistance of the diamondback moth, Plutella xylostella L. (Lepidoptera: Yponomeutidae). Pestic. Biochem. Physiol., 2005, 82, 94-101.

[6] Yu, S.J.; Nguyen, S.N. Insecticide susceptibility and detoxication enzyme activities in permethrin-selected diamondback moths. Pestic. Biochem. Physiol., 1996, 56, 69-77.

[7] Grant, D.B.; Chalmers, A.E.; Wolff, M.A.; Hoffman, H.B.; Bushey, D. F. Fipronil: action at the GABA receptor. Rev. Toxicol., 1998, $2,147-156$

[8] Colliot F.; Kukorowski, K.A.; Hakins, D.W.; Roberts, D.A. Fipronil: A new soil and foliar broad spectrum insecticide. Proc. Brighton Crop Protect. Conf-Pests Dis., 1992, 29, 34.

[9] Wen, Z.M.; Scott, J.G. Genetic and biochemical mechanisms limiting fipronil toxicity in the LPR strain of house fly. Musca domestica. Pest. Sci., 1999, 55, 988-992.

[10] Kristensen, M.; Jespersen, J.B.; Knorr, M. Cross-resistance potential of fipronil in Musca domestica. Pest Manag. Sci., 2004, 60, 894-900.

[11] Mohan, M.; Gujar, G.T. Local variation in susceptibility of thediamonback moth Plutella oxylostella Linnaeus to insecticides and role of detoxification enzymes. Crop Prot., 2003, 22, 495-504.

[12] Li, X.T.; Huang, Q.C.; Yuan, J.Z.; Tang, Z.H. Fipronil resistance mechanisms in the rice stem borer, Chilo suppressalis Walker. Pestic. Biochem. Physiol., 2007, 89, 169-174.

[13] Niu, H.T.; Luo, W.C.; Jiang, G.Q.; Zhu, X.F. Bioactivity of butenefipronil and its field efficacy against diamondback moth, Plutella xylostella (L.). Acta Phytophylacica Sin., 2007, 34, 316-320.

[14] Suderman, R.J.; Dittmer, N.T.; Kanost, M.R.; Kramer, K. J. Model reactions for insect cuticle sclerotization: Cross-linking of recombinant cuticular proteins upon their laccase-catalyzed oxidative conjugation with catechols. Insect Biochem. Mol. Biol., 2006, 36, 353-365.

[15] Arakane, Y.; Muthukrishnan, S.; Beeman, R.W.; Kanost, M. R.; Kramer, K. J. Laccase 2 is the phenoloxidase gene required for bee- tle cuticle tanning. Proc. Natl. Acad. Sci. USA, 2005, 102, $11337-$ 11342.

[16] Ashida, M.; Brey, P.T. Role of the integument in insect defense: pro-phenol oxidase cascade in the cuticular matrix. Proc. Natl. Acad. Sci. USA, 1995, 92, 10698-10702.

[17] Riberio, C.; Simòns, N.; Brehélin, M. Insect immunity: the haemocytes of the armyworm Mythimna unipuncta (Lepidoptera: Noctuidae) and their role in defence reactions. In vivo and in vitro studies. J. Insect Physiol., 1996, 42, 815-822.

[18] Hillyer, J.F.; Christensen, B.M. Mosquitophenoloxidase and defensin colocalize in melanization innate immune responses. J. Histochem. Cytochem., 2005, 53, 689-698.

[19] Liu, N.N.; Zhu, F.; Xu, Q.; Pridgeon, J.W.; Gao, X.W. Behavioral change, physiological modification, and metabolic detoxification: mechanisms of insecticide resistance. Acta Entomol. Sin., 2006, 49, 671-679.

[20] Plapp, F.J.; Hoyer, R.F. Insecticide resistance in the housefly: decreased rate of absorption as the mechanism of action of a gene that act as an intensifier of resistance. J. Econ. Entomol., 1968, 61 , 1298-1303.

[21] Sawicki, R. Interaction between the factor delaying penetration of insecticides and the demethylation mechanisms of resistance to organophosphorus-resistant houseflies. Pestic. Sci., 1970, 1, 84-87.

[22] Wang, S.D.; Luo, W.C.; Xu, S.J.; Ding, Q. Inhibitory effects of 4dodecylresorcinol on the phenoloxidase of the diamondback moth enzymatic properties of Plutella xylostella (L.) (Lepidoptera plutellidae). Pestic. Biochem. Physiol., 2005, 82, 52-58.

[23] Ismail, F.; Wright, D.J. Cross-resistance between acylurea insect grossth regulators in a strain of Plutella xylostella (L.)(Lepidoptera: Yponomeutidae) from Malaysia. Pestic. Sci., 1991, 33, 359-370.

[24] FAO. Method for diamond back moth (Plutella xylostella L.). FAO Plant Prot., 1979, 27, 44-46.

[25] Bradfold, M.M. A rapid and sensitive method for the quantitation of microgram quantities of protein utilizing theprinciple of proteindye binding. Anal. Biochem., 1976, 72, 248-254.

[26] Xue, C.B.; Luo, W.C.; Chen, Q.X.; Wang, Q.; Ke, L.N. Enzymatic properties of phenoloxidase from Pieris rapae (Lepidoptera) larvae. Insect Sci., 2006, 13, 251-256.

[27] Newton, K.; Peters, R.; Raftos, D. Phenoloxidase and QX disease resistance in Sydney rock oysters (Saccostrea glomerata). Dev. Comp. Immunol., 2004, 28, 565-569.

[28] Armitage, S.; Siva-Jothy, M.T. Immune function responds to selection for cuticular colour in Tenebrio molitor. Heredity, 2005, 94, 650-656.

[29] Xu, H.R.; Ling, E.J. Determination of phenoloxidase activity from fifth instar larvae of Bombyx mori. Newslett. Sericult. Tea, 1997, 90, 17-19.

[30] Hoffmann, J.A. Innate immunity of insects. Curr. Opin. Immunol., 1995, 7, 4-10.

[31] Mullen, L.M.; Goldsworthy, G.J. Immune responses of locusts to challenge with the pathogenic fungus metarhizium or high doses of laminarin. J. Insect Physiol., 2006, 52, 389-398.

[32] Bai, J.; Li, Y.Q.; Li, K.R. Study on the effect of monocrotophos on activity of PO in haemolymph of Penaeus chinensis. Marine Sci., 1998, 22, 35-37.

[33] Wu, G.; Shang, Z.Z. Effect of chlorfluazuron on the phenoloxidase and chitinase activity in Ostrinia furnacalis. Acta Entomol. Sin., 1992, 35, 306-310.

[34] Liu, S.Z.; Xiao, T.; Xue, C.B.; Luo, W.C. Physiological effect of quercetin on phenoloxidase from Tenebrio molitor. Acta Entomol. Sin., 2007, 50(12), 1201-1206.

(C) Liu et al.; Licensee Bentham Open.

This is an open access article licensed under the terms of the Creative Commons Attribution Non-Commercial License (http://creativecommons.org/licenses/by-nc/3.0/) which permits unrestricted, non-commercial use, distribution and reproduction in any medium, provided the work is properly cited. 